Anuario Latinoamericano Ciencias Políticas

y Relaciones Internacionales

vol. 7, 2019

pp. 175-192

DOI: 10.17951/al.2019.7.175-192

\section{Empire, Leadership or Hegemony: US Strategies towards the Northern Triangle Countries in the $21^{\text {st }}$ Century}

\author{
Imperio, liderazgo o hegemonía: estrategias de Estados \\ Unidos hacia los países del Triángulo Norte en el siglo XXI
}

\author{
Ieva Giedraityte* \\ INSTITUTE OF INTERNATIONAL RELATIONS AND POLITICAL SCIENCE \\ VILNIUS UNIVERSITY \\ LITHUANIA \\ $\triangle$ ieva.giedraityte@tspmi.vu.lt \\ https://orcid.org/0000-0002-8807-0307
}

\begin{abstract}
The goal of this article is to conceptualize the US strategies towards the Northern Triangle countries during 2005-2015. Using Destradis framework of regional power strategies, this paper analyses strategic documents and secondary sources regarding how US defined goals of its regional cooperation and means for their achievement. It concludes claiming that the US strategy towards the region can be called hegemonic as it was openly subordinated to its needs. Nevertheless, there has been a shift from hard to intermediate hegemony as the US became more perceptive to the needs of its regional partners.
\end{abstract}

KEYWORDS: Northern Triangle, regional powers, regional strategies, empire, hegemony.

\section{RESUMEN}

El artículo sistematiza las estrategias de los EE. UU. hacia los países del Triángulo Norte, siguiendo la categorización de Destradi. Para ello, se ha analizado el contenido de los documentos estratégicos para identificar como los EE. UU. definen sus objetivos en cuanto a la cooperación regional y las medidas para conseguirlos. El texto concluye con la afirmación que la estrategia de los EE.UU. hacia la regi ón puede definirse como hege-

\footnotetext{
* Researcher and Ph.D. student at the Institute of International Relations and Political Science at the University of Vilnius. Master's degree in Latin American Studies from the University of Barcelona (2008-2010). Among her academic interests are processes of cooperation and regional integration in South America (especially in Central America), the strategies of regional powers and the foreign policy of the EU towards the countries of the Global South.
} 


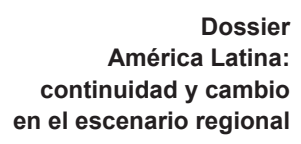

América Latina: continuidad y cambio

PALABRAS CLAVE: Triángulo Norte, poderes regionales, estrategias regionales, imperio, hegemonía.

\section{Introduction}

Central America (CA), an important region for the US during the Cold War, seemed to be forgotten by politicians, academics and broader public since the 90 s until the recurrent migration crisis started at the US border. Unaccompanied minors, mostly from Honduras, Guatemala and El Salvador that reached the US in 2014, sparked public debates and renewed interest in the US-CA relations.

Interestingly, even in the $21^{\text {st }}$ century, studies of US policies in the region often focus on the Cold War period (Colby 2011; Grandin 2006, 2011; Joseph, Grandin 2010; LeoGrande 1998; Travis 2016). Furthermore, the literature tackling US relations with CA is rare, and more often the analysis is done in the broader, Latin American-wide level (e.g., Livingstone 2009, Long 2011, Long and Pastor 2010, Lowenthal et al. 2009). Finally, various authors describe the relationship between the US and its neighbors using concepts coined before the end of the Cold War, without rethinking changes in the US priorities and without a clear definition of the concepts. This article addresses these gaps conceptualizing strategies of the US in CA during 2005-2015. The period has been chosen due to two documents signed by the US during this period: Dominican Republic-Central America Free Trade Agreement (DR-CAFTA), signed in 2005, and US Strategy for Engagement in CA (CA Strategy), adopted at the very end of 2014. Both strategies "frame" a decade of the US involvement in the region.

The first chapter of the article presents the literature on the US policies in Central/Latin America in the $21^{\text {st }}$ century showing a lack of clear conceptualization of US strategies towards the region. The second discusses different theoretical concepts: empire, hegemony and leadership, and, using Destradi's (2010) framework, proposes how to operationalize each strategy. Finally, this framework is applied to the analysis of the US strategy towards CA. This article focuses on the Northern Triangle (NT) countries - Honduras, Guatemala, and El Salvador. All three are by far the biggest recipients of the US aid in the region. Moreover, many of documents dedicated to CA explicitly target the NT sub-region and distinguish these three countries from their neighbors.

After the analysis of strategic US documents, development aid flows and secondary sources, the article concludes claiming that even though the period of analysis covers two different administrations, the main characteristic of the US-CA strategy - its open subordination to the US security objectives - did not change. Thus, I propose to conceptualize it as "hegemonic". Nevertheless, with B. Obama's 
election, the hegemony changed from hard to intermediate as the discourse has softened, making more efforts to include the demands from the partners and designating more funds to enhance the reforms in the neighborhood. The article concludes with the claim that a clear framework focused on what actor does allows clarifying conceptually vague affirmations and adds to a better understanding of regional interactions also outside the Western hemisphere.

\section{Empire and Its Backyard?}

Since the $19^{\text {th }}$ century, the US influence over CA is unquestionable. The US policies in the region before and during the Cold War are widely analyzed (Cox 1994; Mitchener, Weidenmier 2004; Ricard 2006; Stirton Weaver 1994), and the military, economic and ideological dominance of the US over its neighbors during the period is widely acknowledged.

Nevertheless, since the end of the Cold War, the interest of the US policymakers and broader academic community in the region fell. Two regionalscope trends that acquired more scholarly attention were the negotiations and entry into force of DR-CAFTA and, more recently, the rise of insecurity and migration. The latter renewed the discussion about the role of the US in CA, especially in the NT countries. Journalists (Lima 2018; Planas, Grim 2014; Tseng-Putterman 2018), academics critical of the US role in the region (Akram 2018, Chomsky 2018) and even CA presidents (Otto Perez Molina 2014), pointed to the US attempts to dominate the region as one of the root causes for the migration crisis.

The concept of "empire" referring to the US role in the CA (and in the broader sense Latin America) is often paired with the one of "backyard" (Grandin 2001, LeoGrande 1998, Livingstone 2009, Reyna 2016), showing, in this manner, the US dominance over the region and its persistent efforts to maintain it. Nevertheless, many authors do not attempt to define what these terms mean and how their meaning might have changed during different periods. For example, G. Grandin, in his book Empires Workshop: Latin America, the United States, and the Rise of the New Imperialism, traces the "US imperial policies" in Latin America. Connecting the 19th century policies of the US private companies, Cold War and the rise of the so-called "neo-cons" in the US, G. Grandin observes that "it was in CA where the Republican Party first combined the three elements that give today's imperialism its moral force: punitive idealism, free-market absolutism, and right-wing Christian mobilization" (Grandin 2006: 6). He uses the terms of empire and hegemony as synonyms, discussing everything from the US attempts to rearrange Mexican economy or, in general, the promotion of free trade, to military interventions and use of American soft power since 19th century to the War on Terror.

J. Colby (2011) analyses the pre-Cold War events in CA, establishing relations between US private business companies, its racial attitudes and the ex-
Empire, Leadership or Hegemony: US Strategies towards the Northern Triangle Countries in the $21^{\text {st }}$ Century

leva Giedraityte 
Dossier América Latina: continuidad y cambio en el escenario regional panse of its influence in the region. He connects the business model of United Fruits Company with the so-called "American empire," nevertheless, without going into details what empire is and how it works.

G. M. Joseph, in the book Close encounters with Empire (1998), goes even further claiming that he has no interest in the "attenuated debate" about whether the United States constitutes an empire as, according to him "such arguments also ignore structures, practices, and discourses of domination and possession that run throughout U.S. history"(Gilbert 1998: 6). There is no effort to separate what empire is from what it is not. The essays in this volume discuss many facets of the US policies, from movie propaganda to the role of Rockefeller Foundation in CA, always emphasizing the one-sidedness, subordinated position and sense of US superiority. Nevertheless, the clear-cut clarification if all these characteristics are typical to an empire (or imperialist foreign policy) is missing. Long observes this tendency in many works on the US empire in Latin America, as they start with the proclamation of the US as an empire with little attention to the previous usage of the term or attempts to define it (Long 2011: 15).

Loose use of the term "empire" in the discussion about the US foreign policy, especially during the years of G. W. Bush administration, is not limited to Latin American studies. The War on Terror led to the re-birth of academic discussion about the "American empire." The number of adjectives attached to it multiplied: Ferguson (2004) and Mallab (2002) call the US "a reluctant empire"; Cox, an "empire by denial"; Gilderhus (2005), an "informal empire". Prys and Robe (2011) claim that the vision of the US as an empire in the $21^{\text {st }}$ century is based on a particular historical period. According to them, the proponents of "empire" have largely misinterpreted the policy strategy of empire - as applied by the George W. Bush administration - for the real thing, an existing empire (Prys, Robe 2011: 254).

Their proposal to separate a strategy (what actor does) and the status/role (what actor is), becomes a departure point of this article. Instead of asking what the US is in CA/NT, this article focuses on how different US governments engaged with the region. While this approach does not allow easy generalizations (if one maintains hegemonic strategy - is it hegemon or empire in disguise?), it allows seeing variation and change of roles the powerful actors choose for themselves.

\section{Strategies of Regional Powers: Leadership, Hegemony and Empire}

Given the preponderance of the US in comparison to the NT countries, and its attempts to shape the political and economic dynamic in the sub-region, it is analyzed as a regional power. Given that the majority of regional powers are middle powers, their studies do dwell on the idea of domination and pay more attention to the nuances of regional powerhood (see Nolte 2006, 2010; Prys 
2010; Mitchell 2016), regional hegemony and leadership (see Burges 2008, 2015; Flemes 2010; Pedersen 2002; Prys 2008), and strategies of stronger states (Destradi 2010). This article uses the framework of S. Destradi (2010), as it is the most elaborated conceptual attempt to understand not what regional power is, but how it might act towards its corresponding region. According to Destradi, five strategies of engagement: imperial, hegemonic (distinguishing three different types: hard, intermediate and soft), and leadership, can be distinguished based on the following characteristics:

1. Ends of a regional strategy. An attempt to realize regional actor's self-interests tells apart all strategies from the leadership, which is marked by a genuine attempt to achieve objectives important for majority states of the region.

2. Means used to achieve them. While the imperial strategy is distinguished by the reliance on the military intervention (or a threat of it), different hegemonic strategies rely on a broader spectrum of instruments ranging from sanctions and political pressure to economic inducements and normative persuasion/socialization.

3. Self-representation of regional power (e.g., in its documents, speeches of leading politicians) might vary from aggressive/threatening (typical to imperial strategy) to a cooperative (in case of leadership).

4. A discrepancy between the real actions and self-representation. A higher discrepancy is more typical to hegemonic strategies, as the regional power "pretends" to be softer than it is.

5. Legitimation. While in case of imperial and harder hegemonic strategies there would be no or low-level of legitimation, in case of a softer hegemony and leadership the role of regional power would be seen as legitimate by its neighbors.

6. Subordinated states strategies. In the case of "harder" strategies implemented by regional power, countries either intent to resist or obey out of the sheer calculation. In case of a softer hegemony or leadership, they either comply due to changed values or willingly follow its lead.

7. Change in subordinated states' normative orientation. Paradoxically, in case of harder strategies, the change of normative orientations is rarer as states tend to resist.

According to Destradi, "when it comes to operationalizing these concepts for empirical research; however, a reduction in the number of dimensions considered seems to be appropriate" (Destradi 2011: 928). Two characteristics that allow distinguishing different ideal types are a) a commonality or divergence of goals pursued by the regional power and neighboring countries and, b) means employed by the regional power in its relations with these countries. These dimensions are complementary and both necessary: the ends distinguish soft hegemony from leadership; means - empire from hegemony. Moreover, looking at means we can capture different types of hegemonic strategy. Therefore, this article focuses on these two elements of the US-CA strategy, sustaining that while the additional characteristics would help to understand
Empire, Leadership or Hegemony: US Strategies towards the Northern Triangle Countries in the $21^{\text {st }}$ Century

leva Giedraityte 


\begin{tabular}{|c|c|c|c|c|c|c|}
\hline \multirow[t]{4}{*}{$\begin{array}{r}\text { Dossier } \\
\text { América Latina: } \\
\text { continuidad y cambio } \\
\text { en el escenario regional }\end{array}$} & \multicolumn{6}{|c|}{$\begin{array}{l}\text { better the consequences and context of regional strategy, these two are suffi- } \\
\text { cient seeking to characterize it. Table } 1 \text { summarizes the analytical matrix gui- } \\
\text { ding empirical research. }\end{array}$} \\
\hline & & Empire & & Hegemony & & Leadership \\
\hline & & & Hard & Intermediate & Soft & \\
\hline & Ends & Self-interested & Self-interested & Self-interested & Self-interested & Common \\
\hline $\begin{array}{l}\text { Table } 1 . \\
\text { ial strategies that could } \\
\text { e employed by regional } \\
\text { r. In bold: a key feature } \\
\text { at allows to distinguish } \\
\text { the strategy }\end{array}$ & Means & $\begin{array}{l}\text { Military, } \\
\text { Intervention, } \\
\text { threat of } \\
\text { intervention }\end{array}$ & $\begin{array}{l}\text { Sanctions, } \\
\text { threats, } \\
\text { political } \\
\text { pressure }\end{array}$ & $\begin{array}{l}\text { Material } \\
\text { benefits/ } \\
\text { inducements: } \\
\text { economic } \\
\text { side-payments, } \\
\text { military } \\
\text { support }\end{array}$ & $\begin{array}{l}\text { Normative } \\
\text { persuasion, } \\
\text { socialization } \\
\text { (for example, } \\
\text { through joint } \\
\text { working groups } \\
\text { or committees } \\
\text { on contentious } \\
\text { issues) }\end{array}$ & $\begin{array}{l}\text { Normative } \\
\text { persuasion, } \\
\text { socialization } \\
\text { process }\end{array}$ \\
\hline
\end{tabular}

Source: own elaboration.

\section{Us in the Northern Triangle}

Development in international relations after the Iraq war and the consequences of the Great Recession affected the priorities of the US in the region. The first trend led to what some analysts called a "benign indifference" (Loventhal et al. 2009: 43) towards the neighboring region. The second one put the pressure on the US foreign aid capacities, forced to rethink the intervention logic and reconsider finances dedicated to it.

As for Latin America, the primary challenge during the whole period was a so-called left turn taking place in the region. Left-wing governments coming to power in nearly all countries in Latin America tended to have a more critical view of the US role and started various regionalist projects without its participation. The breakup of the US promoted Free Trade Area of the Americas (FTAA) negotiations in 2005 was one of the signs of "rebellion," and the spread of Venezuelan influence was seen as potentially problematic by the US. The NT countries also felt these changes. The Honduran president Manuel Zelaya, elected in 2006, with time forged closer relations with Venezuela, joining Petro Caribe initiative and the Bolivarian Alternative for the Americas (ALBA). The rule of M. Zelaya was disrupted by the coup in 2009, finishing 27 years of peaceful civilian rule. In the same year, after 20 years of right-wing party rule, a left-wing party, formed by former guerrillas won presidential elections in El Salvador. It can be concluded that by the end of the first decade of the $21^{\text {st }}$ century, politicians searching for more autonomy replaced the actively pro-American presidents. Further- 
more, the security was becoming more relevant. The homicide rates were growing in all three countries until the second decade of the $21^{\text {st }}$ century. Especially violent changes took place in Honduras between 2007 until 2011 and in El Salvador between 2013 and 2015, when murder rates grew two to three times (World Bank data) and finally insecurity became one of the reasons for migration, which reached the peak in 2014 .

To sum up, two trends were shaping the US-NT relations: a diminishing role of the US in the region and the growing importance of the NT to the US through the security challenges and migration flows. The two US administrations approached these changes in somewhat similar, and yet, different way.

\section{George W. Bush Administration}

\section{A. Ends of the Regional Strategy}

In 2001, George W. Bush claimed that the primary goal of his presidency was "to ignite a new era of economic growth through a world trading system that is dramatically more open and free." (Bush 2001). Thus, the signature of DRCAFTA was reflecting one of the main objectives of his presidency. During the period 2005-2009 the second biggest thematic group of projects financed by the US in three NT countries was related to economic liberalization (Table 2). The exception was Guatemala, where economy-oriented projects were somewhat marginal, partially due to the fact that Guatemala was tackling painful recovery process after the civil war and support for the Peace Accords and stability was a more immediate priority.

\begin{tabular}{lccc}
\hline \multicolumn{4}{c}{$2005-2009$} \\
\hline \multicolumn{1}{c}{ Thematic group } \\
DA & El Salvador & Honduras & Guatemala \\
Governance & 36.7 & 49.5 & 69.3 \\
Economy & 9.6 & 6.3 & 11.9 \\
Security & 26.6 & 37.1 & 7.8 \\
Total & 27.2 & 7.1 & 11.0 \\
\hline
\end{tabular}

${ }^{*} \mathrm{DA}$ (Development aid) - projects in "traditional" development assistance field, such as healthcare, agriculture, environment, education. Governance: decentralization, strengthening of political system and institutions, support to human rights and independent media. Economy: economic liberalization, economic infrastructure, strengthening the private sector, support for DR-CAFTA. Security: military support, training of the police, community security programs. Source: USAID.

Similarly, the amount of aid disbursed for projects related to the economic transformation was growing - many of the funds were going directly to support the implementation of DR-CAFTA (Graph 1).
Empire, Leadership or Hegemony: US Strategies towards the Northern Triangle Countries in the $21^{\text {st }}$ Century

leva Giedraityte
Table 2.

Thematic distribution of projects financed by the US in three North Triangle countries (disbursements) in 2005-2009 


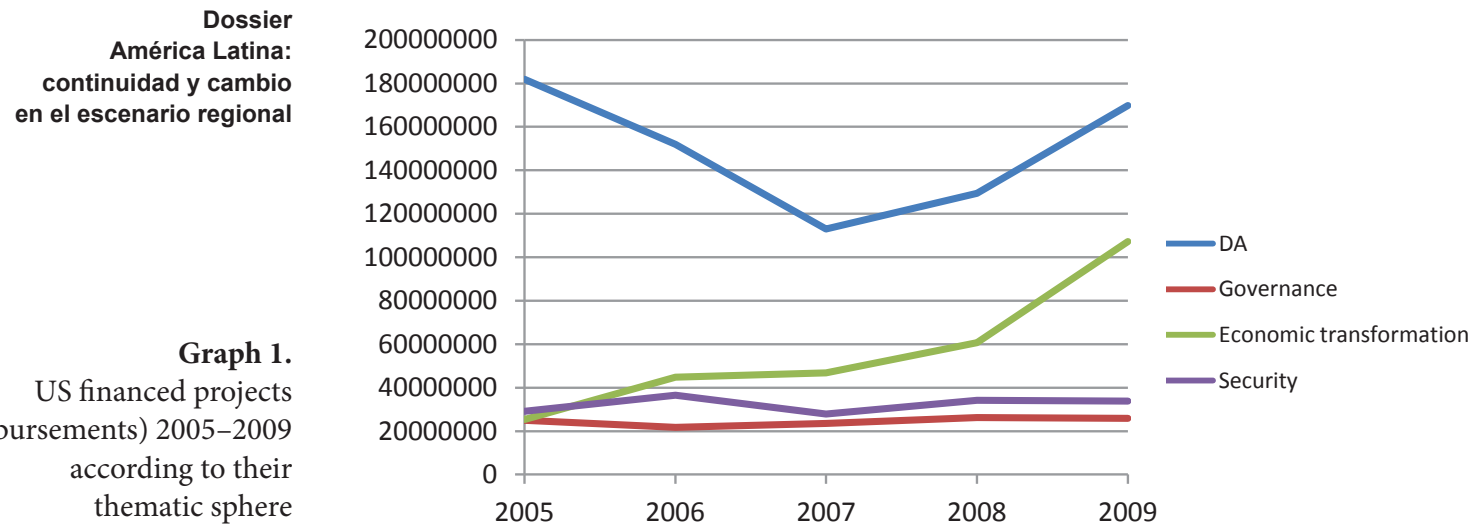

Source: USAID.

The political elites of CA were actively seeking the signature of DR-CAFTA due to the losses after the entrance into force of NAFTA (Condo et al. 2005: 8). Nevertheless, the opening of the negotiation was more related to the foreign policy goals (failure to secure the FTAA because of a spread of "socialism of the $21^{\text {st }}$ century") and general "freedom" agenda of Bush's administration, than an active push from CA.

The US administration saw DR-CAFTA not only as merely commercial but rather as a transformative agreement, "adding up" to the democratization of the neighborhood. As the official position of US government stated: "The CAFTA-DR is a regional trade agreement among all seven signatories, and will contribute to the transformation of a region that was consumed in internal strife and border disputes just a decade ago" (USTR 2004: 1). The transformation should come through the "more open and transparent procedures, which should deepen the roots of democracy, civil society, and the rule of law in the region, as well as reinforce market reforms" (USTR 2004: 3). Thus, given the marginal importance of CA in the US export market, the signature of the treaty was instead a demonstration of the power and success of US "pushy" free trade agenda, which seemed stuck after the collapse of the FTAA negotiations and the delays in the FTA negotiations with Australia and Morocco.

Second, the way the DR-CAFTA was negotiated shows unequal power setting - the negotiations for the initial agreement were very brief, bearing in mind the number of countries involved and the disparities between the Southern Countries. Similarly, in most of the cases, the US had the lead in the pace of the negotiations, being the first to propose its position or initial draft versions of the documents, often basing them on the FTA with Chile (Gonzalez 2006: i). The US has been reluctant to make concessions, given that the negotiations were seen as an example and blueprint to future FTA negotiations (Gonzalez 2006: 85). Hence, while the governments of CA countries suppor- 
ted the agreement, the negotiations and the final agreement strongly reflected the needs (rather political than economic) of the US and its broader foreign policy agenda.

The expected regional transformation did not happen, and the security situation worsened. As a response, a so-called Merida initiative was designed to tackle transnational crime in Mexico and CA (mostly NT). Its funds were used to bolster the capacity of government to inspect and interdict drugs and to support the US Strategy for Combating Criminal Gangs from CA and Mexico, (Cook, Rush, Ribando Seelke 2008: 2). Nevertheless, different security strategies did not mean a steep jump in security-related projects - as can be seen in graph 2, their value between 2007 and 2008 grew less than by $8 \%$.

Concluding, the major preoccupation of the US in the NT was related with the broader foreign policy goals (DR-CAFTA as a continuation of ambitious Latin American scale policies) and security issues, mostly related with the spillover of insecurity from Mexico and Colombia. While fighting this phenomenon was in the interests of the NT countries, the US policies primarily centered on its needs. For example, while the NT countries were claiming that the deportations of their citizens are aggravating gang situation, the US migration services were not indicating which of the deportees were belonging to the gangs, unless this was the primary reason of deportation (Ribando Seelke 2016). Similarly, the push from Latin America to tackle drug consumption instead of fighting the production or tackling the lax gun laws production passed unheard. Thus, regarding its goals, the US strategy towards CA can be considered as imperial or hegemonic. However, the analysis of means used to achieve these goals is needed to define which category of these two is more suitable.

\section{B. Means to Achieve Them}

Since the attack on Panama in 1989, the US has never used open military force in the region and, thus, according to the framework of Destradi, the US strategy was hegemonic, not imperialist. Nevertheless, its governments have never ceased picturing the US as a natural leader of the region, claiming that "while we do not seek to dictate to other states the choices they make, we do seek to influence the calculations on which these choices are based. We also must hedge appropriately in the case states choose unwisely" (NSS 2006: 41). One of the principal instruments was foreign financial assistance which in internal documents on the US foreign aid was called "one of the tools the United States employs to advance US interests in Latin America and the Caribbean, and the focus and funding levels of aid programs change along with broader US policy goals" (Meyers 2018: 1).

The importance of FTAA and later of DR-CAFTA agreement led to significant US pressure for countries to sign the deal. In Costa Rica, which was the last one to sign DR-CAFTA agreement and only after the close win of the agreement's supporters in the referendum, before the voting the US ambassador M. Langdale often repeated the threat that country would lose the existing
Empire, Leadership or Hegemony: US Strategies towards the Northern Triangle Countries in the $21^{\text {st }}$ Century

leva Giedraityte 
Dossier América Latina: continuidad y cambio en el escenario regional preferential treatment in case of negative voting. These threats were angrily picked up by agreement's opponents in the US Congress, stating that the US is not going to retaliate to the countries deciding against the free trade agreements (Congressional Records 2007: H11132).

For those willing to sign the agreement the possibility of US blocking it, was a strong motivator to support military intervention in Iraq. All three NT countries not only supported the war (despite generalized opposition in Latin America led by Mexico, Chile, and Brazil) but also sent a small number of soldiers to support the mission. The DR-CAFTA treaty has been signed, and countries received military aid. Moreover, in aid programming documents elaborated under the administration of G. W. Bush, this choice was always mentioned as a demonstration of the will to cooperate.

Furthermore, during this period, smaller countries were aware of the possibility of sanctions in case of not supporting US foreign policy goals. For example, they were quick to sign the so-called Article 98 Agreements, stipulating that signatory countries were agreeing not to hand over US citizen to the International Criminal Court. The massive US-led campaign against the Court's Jurisdiction was accompanied with the pressure and threats to cut off the military and economic aid given to the countries. All NT countries signed Article 98 Agreements, El Salvador being the first country in Latin America to do that. The price of not signing was real - Costa Rica, which, together with other 11 countries, refused to sign it, was temporarily refused military and economic aid. By 2009, most of the Article 98 limitations were lifted, due to concerns of G. W. Bush administration that it could lead to diminishing of US role in these countries (Ribando Seelke 2006). To sum up, the instruments used by the US: political pressure, sanctions or economic rewards, indicate that we cannot call the US strategy imperial, as, according to the framework of Destradi, the latter is defined by military intervention. However, the selfish goals, together with economic and political pressure and rewards, indicate the use of hard hegemonic strategy towards the NT countries during the period of analysis.

\section{Barack Obama Administration}

\section{A. Ends of the Regional Strategy}

Implemented projects and strategic documents show that at the beginning of Barack Obama presidency, there was more continuity than change. For example, the priorities of the US in CA countries, enumerated in Congressional Budget Justification for Foreign Operations acts (democratization, economic growth, and security) did not change substantially between two administrations. Moreover, supporting economic liberalization or rather "ensuring an economic growth" still was among the main priorities. In 2010, Obama launched a new presidential initiative, a Partnership for Growth, to accelerate and 
sustain broad-based economic growth. El Salvador became one of the first countries to take part in it. As well, fostering economic growth became one of the priorities in Guatemala's and Honduras country development strategies key documents for the USAID involvement in the countries. Nevertheless, as can be seen in the graph 2 , since 2010, the number of directly economy-related projects and interventions fell sharply.

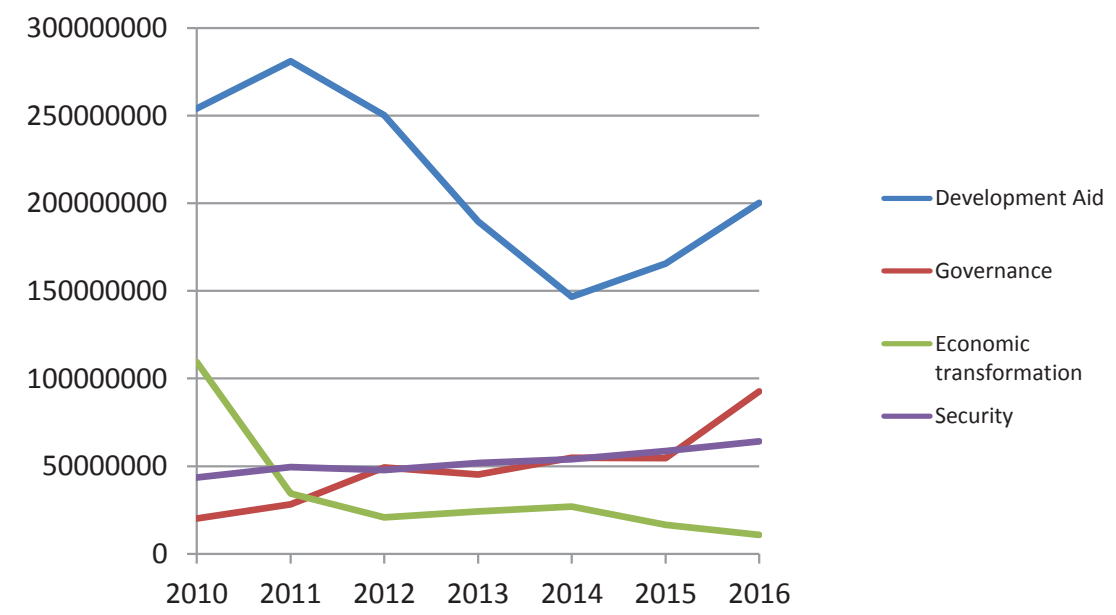

Source: USAID.

The concerns related to economic growth were pushed aside by growing security issues. The increasing homicide rates in CA, drug trafficking and growing drug-related violence led to the shift in the US involvement. In 2010, from the CA branch of Merida initiative, the CA Regional Security Initiative (CARSI) was created. Officially it "was supposed to take a broad approach to the issue of security that goes well beyond the traditional focus on preventing narcotics from reaching the United States" (Meyer, Ribando Seelke 2013: 2).

Growing migratory pressures and insecurity "brought back" the NT countries to National Security Strategy in 2015. Similarly, the CA Strategy and USAID Regional Strategy for CA and Mexico, adopted respectively at the end of 2014 and in 2015, reflect the fear related to the instability in the sub-region. CA Strategy mentions different trends taking place in the region (i.e., economic "deficiencies", high energy costs, growing population, climate change) as a source of threats. According to the document, "implications are stark for the United States if the aforementioned concerns become a trend. More than five million Central Americans are expected to join the workforce over the next decade, many of them in Guatemala and Honduras. If economic prospects remain poor, and the crime rate remains high, migration and organized crime may present challenges for the United States and Mexico" (CA Strategy
Empire, Leadership or Hegemony: US Strategies towards the Northern Triangle Countries in the $21^{\text {st }}$ Century

leva Giedraityte

\section{Graph 2.}

US financed projects

(disbursements) 2010-2016

according to their thematic sphere 


\begin{tabular}{|c|c|c|c|c|}
\hline \multirow[t]{8}{*}{$\begin{array}{r}\text { Dossier } \\
\text { América Latina: } \\
\text { continuidad y cambio } \\
\text { en el escenario regional }\end{array}$} & \multicolumn{4}{|c|}{$\begin{array}{l}\text { 2014). Thus, the growing number of governance and development aid pro- } \\
\text { jects, which can be seen in the table } 3 \text {, also can be explained by the fact that } \\
\text { more facets of CA reality were seen as dangerous. }\end{array}$} \\
\hline & \multicolumn{4}{|c|}{$2014-2016$} \\
\hline & & El Salvador & Honduras & Guatemala \\
\hline & DA & 39.4 & 49.6 & 63.1 \\
\hline & Governance & 27.5 & 29.2 & 14.4 \\
\hline & Economy & 19.7 & 2.7 & 2.7 \\
\hline & Security & 13.4 & 18.6 & 19.8 \\
\hline & Total & $100 \%$ & $100 \%$ & $100 \%$ \\
\hline & \multicolumn{4}{|c|}{$2010-2013$} \\
\hline Table 3. & & El Salvador & Honduras & Guatemala \\
\hline Thematic distribution & DA & 75.2 & 49.2 & 60.6 \\
\hline of projects financed & Governance & 7.1 & 10.2 & 14.7 \\
\hline by the US in three & Economy & 9.7 & 27.7 & 3.8 \\
\hline (disbursements) & Security & 8.0 & 12.9 & 20.9 \\
\hline during 2010-2017 & Total & $100 \%$ & $100 \%$ & $100 \%$ \\
\hline
\end{tabular}

Source: USAID.

While opening himself to an alternative approach towards drug-related problems, B. Obama was strict about deportation policy, and the number of deported illegal migrants steadily grew since his election despite CA countries protests. The so-called removals reached their peak in 2014 when, compared to 2005, 3.6 times more people were removed from the US (US Customs and Border Protection). Additionally, as a foreign assistance program, CARSI was unable to address two of the principal factors contributing to insecurity the US migration policy (including the large-scale deportation of criminal youth) and the widespread availability of trafficked firearms (Olson et al. 2015: 10). Concluding, the strong primacy of the US foreign policy goals indicates the continuation of hegemonic strategy towards the region. However, we need to study the means used by the US in order to define the type of hegemonic strategy.

\section{B. Means to Achieve Them}

While the discourse of partnership has never disappeared from official documents, B. Obama distinguished himself as being more "inclusive." The proposed approach to CA problems foresaw three groups of actions: convening different partners to establish a common understanding of the problem, developing a shared vision with CA countries and establishing a mechanism to coordinate international support for a region. Hence, at least theoretically, more emphasis was given and space foreseen for socialization processes both between the US and CA countries and between the US, CA and other donors. 
In the meeting with Obama, that took place on July 2014, three presidents of the NT countries criticized US response to the migration crisis, as too focused on border security and pleaded to attend the "root causes" of migration: drug violence and lack of economic opportunities. Their demands were at least partially heard as at the end of the same year, under the guidance of the Inter-American Development Bank (IABD), they elaborated the so-called "Plan Alliance for Prosperity" (PAP), establishing main lines for their countries. Despite being criticized for its speedy preparation and exclusion of civil society from the process (Pineda and Matarmoso 2017: 38-39), PAP was aligned with NT priorities and national development plans. It also became a source for alignment for the CA Strategy, showing that the US government was at least officially hearing the proposals formulated by the governments of the region.

Moreover, the funds designated to CA grew since 2009. As it can be seen in the graph 3, despite the fall in the disbursements for the projects implemented by US agencies in the NT countries between 2010 and 2013, the amount of financial aid was growing steadily under the Obama government, with a steep jump in 2015.

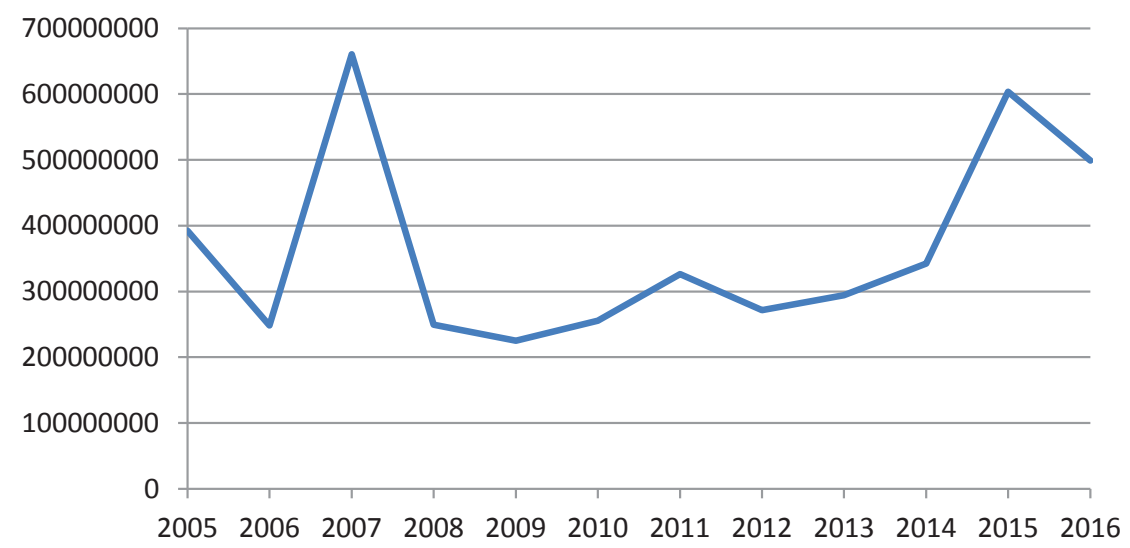

Source USAID.

Seeking congressional approval for growing expenditures, the CA Strategy was presented as a conditional agreement rather than a development plan. A commitment of the NT (and more broadly speaking, CA) countries to the reforms were mentioned in various discourses presenting CA Strategy (e.g., Biden 2015). For its part, Congress has placed strict conditions on the aid. A $75 \%$ was conditional to the implementation of specific policies, ranging from the management of migration flows (including the cooperation with the US agencies in the repatriation of illegal migrants proceeding from these countries) and improving border security to the transparency of governance
Empire, Leadership or Hegemony: US Strategies towards the Northern Triangle Countries in the $21^{\text {st }}$ Century

leva Giedraityte

Graph 3.

US Obligations in NT Countries 2005-2016 (2016 USD) 
Dossier América Latina: continuidad y cambio en el escenario regional and persecution of human right abusers (Consolidated Appropriations Act 2016: 554-555). The State Department was responsible for checking the fulfillment of a long list of conditions, which delayed the disbursements (Meyer 2019: 11).

To sum up, the main change in the US strategy during the Obama administration was related to the means rather than its ends. While latter were still subordinated to US foreign policy goals, material payments and military support took the place of open political pressure and a threat of sanctions. Hence, the strategy implemented by Obama was corresponding to intermediate hegemonic strategy. What is more, the emphasis on cooperation and joint problem solving is also typical to soft hegemonic strategy and, thus, there was a shift towards it at the end of the period.

\section{Conclusions}

This article applies Destradi's framework of regional power strategies in order to conceptualize the US strategies towards the NT countries during two consecutive US administrations: G. W. Bush and B. Obama. From seven dimensions proposed by Destradi, only two (ends and means used) are analyzed, as only they are necessary, complementary and sufficient features to understand the type of regional strategy employed. Looking at the results of the comparison, we can observe both continuity and change. The primary goal of G.W. Bush administration was related to the economic opening of the region, while B. Obama had a more ambitious and holistic vision of neighborhood transformation. Moreover, the unilateralist push in the post-Iraq war context gave place to a broader regional level coalition building, seeking to address the unaccompanied minor migrant crisis of 2014.

Nevertheless, in both cases, the primary motivation of the US was its pressing needs and its security. The NSS of 2006 states that "If America's nearest neighbors are not secure and stable, then Americans will be less secure." A similar rationale can be observed in the CA Strategy, claiming that "U.S. security is intimately linked to the security and prosperity of CA" (CA Strategy 2014). Thus, both administrations were implementing hegemonic strategies yet, during the period of analysis, there was a shift from hard to intermediate hegemony. Table 4 summarizes these findings.

These variations can be hidden under broad and loosely defined concepts such as an "empire" or "colossus," in this manner hiding the peculiarities of the US power and limiting the analytical usefulness of the concepts themselves. Future research could focus on the policies of Donald Trump administration, seeking to compare how two similar migration crisis, 2014 and 2017, changed the US strategy under two different administrations. Besides, the expansion of the framework to other dimensions, such as legitimation, subordinate states strategies and changes in their internal norms, would also be necessary, as 
it could also allow to discuss the effectiveness of different strategies. A clear framework focused on what actor does instead of on what actor is, allows not only to understand better the US policies, but also to compare them in time (between the administrations) and, even more importantly, with the ones of other regional powers. Such comparisons would help to overcome the ideas about the US exceptionalism and, consequently, understand better the relationship dynamics between different powerful actors and their neighbors.

\begin{tabular}{|c|c|c|}
\hline & \multicolumn{2}{|c|}{ Hegemonic strategy } \\
\hline & $\begin{array}{l}\text { Hard } \\
2005-2009 \\
\text { G.W. Bush administration }\end{array}$ & $\begin{array}{l}\text { Intermediate } \\
2010-2015 \\
\text { B. Obama administration }\end{array}$ \\
\hline Ends & $\begin{array}{l}\text { Self-interested } \\
\text { US Strategy in Central America is } \\
\text { clearly subordinated to the foreign } \\
\text { policy goals: free trade agenda and } \\
\text { support of the Iraq war. }\end{array}$ & $\begin{array}{l}\text { Self-interested } \\
\text { US Strategy in Central America is } \\
\text { subordinated to the US security } \\
\text { agenda: first, drug trafficking and } \\
\text { gangs; later, migration management. }\end{array}$ \\
\hline Means & $\begin{array}{l}\text { Sanctions, threats, political pressure: } \\
\text { - political pressure and threats of } \\
\text { financial sanctions in CAFTA } \\
\text { negotiations; } \\
\text { - financial sanctions for those, not } \\
\text { signing Article } 98 \text { Agreements; } \\
\text { - pressures for the support of Iraq } \\
\text { war. }\end{array}$ & $\begin{array}{l}\text { Material benefits/ inducements } \\
\text { (economic side-payments, military } \\
\text { support): } \\
\text { - } \text { rise in financial support, } \\
\text { nevertheless with the strong } \\
\text { conditionality causing delays; } \\
\text { - military support: reframing } \\
\text { Merida's Central American branch } \\
\text { into CARSI; } \\
\Rightarrow \text { Shift towards soft hegemonic } \\
\text { strategy (?): normative persuasion } \\
\text { and socialization through joint } \\
\text { initiatives and working groups. }\end{array}$ \\
\hline
\end{tabular}

Source: own elaboration.
Empire, Leadership or Hegemony: US Strategies towards the Northern Triangle Countries in the $21^{\text {st }}$ Century leva Giedraityte
Table 4.

US Strategies in Central America 2005-2015

\section{Bibliographic references}

Akram S. M. (2018), What's Driving the Migration Crisis at Our Southern Border?, "Boston's NPR News Station", https://www.wbur.org/cognoscenti/2018/08/08/why-do-migrantsflee-central-america-susan-akram, access: 11.07.2018.

Biden J. (2015), Plan for Central America, “The New York Times”, https://www.nytimes. com/2015/01/30/opinion/joe-biden-a-plan-for-central-america.html, access: 11.07.2018.

Burges S. W. (2008), Consensual Hegemony: Theorizing Brazilian Foreign Policy After the Cold War, "International Relations", 22 (1), pp. 65-84.

Burges S. W. (2015), Revisiting Brazil's Consensual Hegemony in South America: Brazilian Regional Leadership in Question, "International Politics", 52 (2), pp. 193-207. 
Dossier América Latina: continuidad y cambio en el escenario regional
Chomsky N. (2018), Migrants Are Fleeing Horrors Created by the U.S. in Latin America, "Haaretz", https://www.haaretz.com/us-news/noam-chomsky-migrants-are-fleeing-horrorscreated-by-the-u-s-1.6695006, access: 11.11.2018.

Colby J. (2011), The Business of Empire: United Fruit, Race, and U.S. Expansion in Central America, Cornell University Press, Ithaca.

Congressional Record Proceedings and Debates of the 110th Congress, First Session (2007) https://www.congress.gov/crec/2007/10/02/CREC-2007-10-02.pdf, access: 10.02.2018

Consolidated Appropriations Act (2016), Public Law 114-113, https://www.congress. gov/114/plaws/publ113/PLAW-114publ113.pdf, access: 11.02.2018

Cook C.W., Rush R. G., Seelke C. R. (2008), Mérida Initiative: Background and Funding, "Congressional Research Service Report", https://www.wola.org/sites/default/files/ downloadable/Mexico/past/CRS\%20report.pdf, access: 11.02.2018.

Cox M. (2004), Empire by Denial? Debating US Power, "Security Dialogue", vol. 35, no 2, pp. 228-236.

Destradi S. (2010), Regional Powers and Their Strategies: Empire, Hegemony and Leadership, "Review of International Studies", (36) 4 , pp. 903-930.

Flemes D. (2010), Regional Leadership in the Global System, Ashgate Publishing.

González A. (2006), El proceso de negociación de un tratado de libre comercio con Estados Unidos: La experiencia del tratado de libre comercio entre Centroamérica, Estados Unidos y República Dominicana, Documento de divulgación INTAL-ITD, https://publications. iadb.org/en/publication/13472/el-proceso-de-negociacion-de-un-tratado-de-librecomercio-con-estados-unidos-la, access: 01.03.2018.

Grandin G. (2004), The Last Colonial Massacre. Latin America in the Cold War, The University of Chicago Press.

Grandin G. (2006), Empires Workshop: Latin America, the United States, and the Rise of the New Imperialism, Metropolitan Books, New York.

Joseph G. M., Grandin G. (2010), A Century of Revolution: Insurgent and Counterinsurgent Violence during Latin America's Long Cold War, Duke University Press.

LeoGrande W. (1998), Our Own Backyard: The United States in Central America, 19771992, University of North Carolina Press.

Lima L. (2018), Caravana de migrantes: ¿qué rol ha tenido Estados Unidos en la violencia, la pobreza y la falta de oportunidades que padecen Honduras, Guatemala y El Salvador?, "BBC", https://www.bbc.com/mundo/noticias-america-latina-45973286, access: 01.02.2018.

Livingstone G. (2009), America's Backyard: The United States and Latin America from the Monroe Doctrine to the War on Terror, Latin American Bureau, Zed Books.

Long T. (2013), Convincing the Colossus: Latin American Leaders Face the United States, doctoral dissertation, American University.

Lowenthal A. F., Piccone T. J., Whitehead L. (2011), Shifting the Balance: The Obama Administration and the Americas, Brookings Press.

Mallab S. (2002), The Reluctant Imperialist: Terrorism, Failed States, and the Case for American Empire, "Foreign Affairs", vol. 81, no 2, pp. 2-7.

Meyer P.J. (2018), U.S. Foreign Assistance to Latin America and the Caribbean: FY2018 Appropriations, "Congressional Research Service Report", https://fas.org/sgp/crs/row/ R45089.pdf, access: 01.03.2018. 
Meyer P.J., Ribando Seelke C. (2013), Central America Regional Security Initiative: Background and Policy Issues for Congress, "Congressional Research Service Report", https://securityassistance.org/sites/default/files/R4173, access: 01.06.2018.

Meyer, P. J. (2018), U.S. Foreign Assistance to Latin America and the Caribbean: FY2018 Appropriations, "Congressional Research Service Report", https:/fas.org/sgp/crs/row/ R45089.pdf, access: 01.05.2018.

Mitchener K. J., Weidenmier M. (2004), Empire, Public Goods, and the Roosevelt Corollary, "NBER Working Paper", http://www.nber.org/papers/w10729, access: 01.05.2018.

Mitchell D. (2016), Regional Power? Yes, but What Kind?, paper presented at International Studies Association Asia-Pacific, Hong Kong, June 25-27 2016, http://web.isanet.org/ Web/Conferences/AP\%20Hong\%20Kong\%202016/Archive/a6e97a55-34b4-4b63-9f952b7c47f2a231.pdf, access: 01.05.2018.

Nolte D. (2010), How to Compare Regional Powers: Analytical Concepts and Research Topics, "Review of International Studies", no 36, pp. 881-901.

Nolte D. (2006), Regional Powers in International Relations: Analytical Concepts and Research Approaches, GIGA Working Paper no 30, available at SSRN: https://ssrn.com/ abstract $=940338$ or http://dx.doi.org/10.2139/ssrn.940338, access: 17.07.2018.

Office of the United States Trade Representative (2004), Statement of Why the Dominican Republic-Central America-United States Free Trade Agreement Is in the Interests of U.S. Commerce, https:/ustr.gov/sites/default/files/uploads/Countries\%20Regions/africa/agreements/cafta/ Statement\%20of\%20Why\%20the\%20U.S.-CAFTA-DR\%20FTA\%20is\%20in\%20the\%20 Interests\%20of\%20U.S.\%20Commerce.pdf, access: 01.05.2018.

Olson E. L. (ed.) (2015), Crime and Violence in Central America's NT. How U.S. Policy Responses are Helping, Hurting, and Can Be Improved, "Woodrow Wilson Center Reports on the Americas", https://www.everycrsreport.com/files/20160829_RL34112_519fde01d8c 18be18782d65f61c168949bea7d81.pdf, access: 01.07.2018.

Pastor R. A. (1986), Explaining U.S. Policy Toward the Caribbean Basin: Fixed and Emerging Images, "World Politics", vol. 38, no 3, April, pp. 483-515.

Pastor R. A., Long T. (2010), Cold War and Its Aftermath in the Americas: The Search for a Synthetic Interpretation of U.S. Policy, "Latin American Research Review", vol. 45, no 3, pp. 261-273.

Pedersen T. (2002), Cooperative Hegemony: Power, Ideas and Institutions in Regional Integration, "Review of International Studies", vol. 28, no 4, October, pp. 677-696.

Pérez Molina O. (2014), In Latin America, We Know Who Is to Blame for Our Child Migrant Crisis, "The Guardian", https://www.theguardian.com/commentisfree/2014/aug/03/child-migrantsto-us-guatamalan-president-on-human-rights-action-on-traffickers, access: 01.07.2018.

Pineda A. H., Matamoros A. L. P. (2016), Planteamiento de CIPRODEH: Plan de la Alianza para la Prosperidad del Triángulo Norte, CIPRODEH.

Planas R., Grim R. (2014), Here's How The U.S. Sparked a Refugee Crisis on the Border, In 8 Simple Steps, "The Huffington Post", https://www.huffingtonpost.com/2014/07/18/refugeecrisis-border_n_5596125.html, access: 01.07.2018.

Prys M. (2010), Hegemony, Domination Detachment: Differences in Regional Powerhood, "International Studies Review", 12(4), pp. 479-504.

Reyna S. (2006), Deadly Contradictions: The New American Empire and Global Warring, Berghahn Books.
Empire, Leadership or Hegemony: US Strategies towards the Northern Triangle Countries in the $21^{\text {st }}$ Century

leva Giedraityte 
Dossier América Latina: continuidad y cambio en el escenario regional
Ribando Seelke C. R. (2006), Article 98 Agreements and Sanctions on U.S. Foreign Aid to Latin America, Congressional Research Service Report, https://digital.library.unt.edu/ ark:/67531/metacrs8995/m1/1/high_res_d/RL33337_2006Apr10.pdf, access: 01.09.2018.

Ribando Seelke C. R. (2013), Gangs in Central America, Congressional Research Service Report, https://www.hsdl.org/?abstract\&did=730334, access: 01.09.2018.

Ribando Seelke C. R. (2016), Gangs in Central America, Congressional Research Service Report, https://fas.org/sgp/crs/row/RL34112.pdf, access: 15.09.2018.

Ricard S. (2006), The Roosevelt Corollary, "Presidential Studies Quaterly", vol. 36, Issue 1, pp. 17-26.

Shor F. (2009), Dying Empire: U.S. Imperialism and Global Resistance, Routledge, London.

The National Security Strategy of United States of America (2015), https://obamawhitehouse. archives.gov/sites/default/files/docs/2015_national_security_strategy_2.pdf, access: 01.09.2018.

The National Security Strategy of United States of America (2006), https://www.state.gov/ documents/organization/64884.pdf, access: 01.09.2018.

Travis P. (2017), Reagan's War on Terrorism in Nicaragua - The Outlaw State, Lexington Books, Lanham.

Tseng-Putterman M. (2018), A Century of U.S. Intervention Created the Immigration Crisis, "Medium", https://medium.com/s/story/timeline-us-intervention-central-americaa9bea9ebc148, access: 01.11.2018.

USAID Foreign Aid Explorer, https://explorer.usaid.gov/, access: 15.09.2018.

US Customs and Border Protection, https://www.cbp.gov/ access: 15.09.2018.

US Strategy for Engagement in Central America (2014), https://obamawhitehouse.archives. gov/sites/default/files/docs/central_america_strategy.pdf, access: 15.07.2018. 